\title{
EVALUATION OF TOURIST ATTRACTIVENESS AND MUSEUM MANAGEMENT IN SOMBOR AND APATIN (SERBIA)
}

Vanja Dragićević, Snežana Besermenji, Tatjana Pivac, Anđelija Ivkov-Džigurski, Kristina Košić

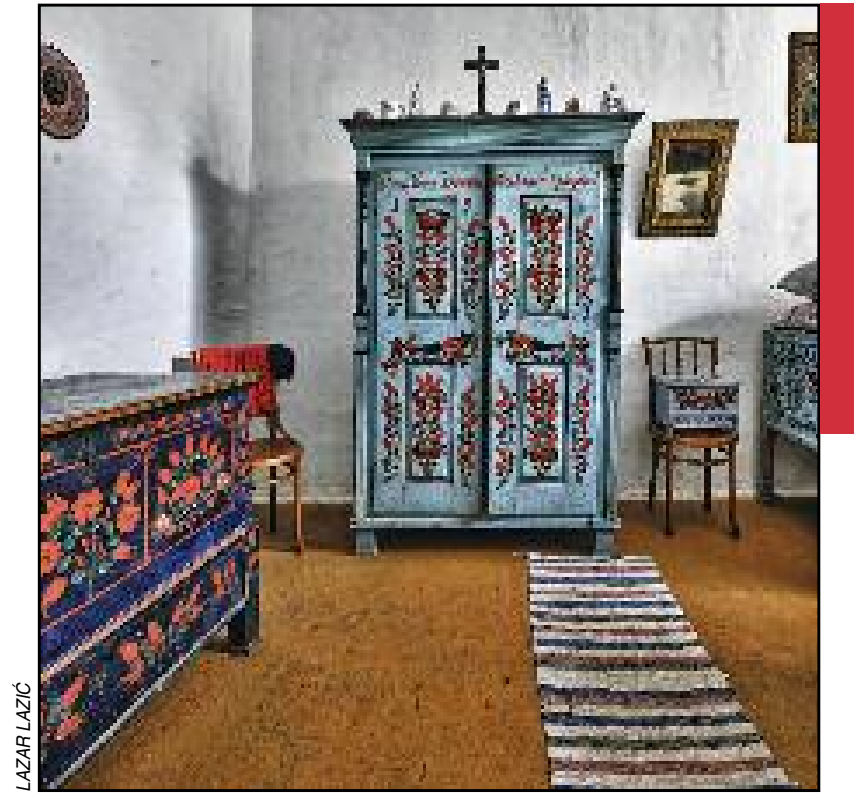

Ethno Exhibition in Kupusina, Vojvodina Province, Serbia. 


\section{Evaluation of tourist attractiveness and museum management in Sombor and Apatin (Serbia)}

DOI: $10.3986 / A G S 53405$

UDC: $913: 338.483 .12(497.113)$

338.486(497.113)

COBISS: 1.01

ABSTRACT: In the area of Sombor and Apatin there are a number of cultural institutions. The paper will cover the Museum of silk damask in Bezdan, Tobacco Museum in Telečka and the Ethnological Exhibition in Kupusina. The aim of this paper is to assess the market attractiveness, the sensitivity of cultural property, the state of repair, the existence of cultural property management plan, regular monitoring and maintenance, potential for ongoing investment, the possibility of a negative impact of a large number of visitors to the physical condition of cultural resources and the possibility of modifications as part of the product development.

KEY WORDS: museums, market attractiveness, management, Sombor, Apatin, rural development, tourism

\section{ADDRESSES:}

Vanja Dragićević, Ph. D.

Department of Geography, Tourism and Hotel Management

Faculty of Sciences

University of Novi Sad

Trg Dositeja Obradovića 3, 21000 Novi Sad, Serbia

E-mail:drvanja@yahoo.com

\section{Snežana Besermenji, Ph. D.}

Department of Geography, Tourism and Hotel Management

Faculty of Sciences

University of Novi Sad

Trg Dositeja Obradovića 3, 21000 Novi Sad, Serbia

E-mail: atena21000@yahoo.com

\section{Tatjana Pivac, Ph. D.}

Department of Geography, Tourism and Hotel Management

Faculty of Sciences

University of Novi Sad

Trg Dositeja Obradovića 3, 21000 Novi Sad, Serbia

E-mail: tatjana_pivac@yahoo.com

\section{Anđelija Ivkov-Džigurski, Ph. D.}

Department of Geography, Tourism and Hotel Management

Faculty of Sciences

University of Novi Sad

Trg Dositeja Obradovića 3, 21000 Novi Sad, Serbia

E-mail: ivkova@gmail.com

\section{Kristina Košić, Ph. D.}

Department of Geography, Tourism and Hotel Management

Faculty of Sciences

University of Novi Sad

Trg Dositeja Obradovića 3, 21000 Novi Sad, Serbia

E-mail: tinicaus@yahoo.com 


\section{Contents}

406

2 Literature review

406

Methodology

407

Results

408

5 Conclusion

413

6 Acknowledgment

413

7 References

413 


\section{Introduction}

The change of the social, economic and political system in Serbia at the beginning of the new millennium also marks the start of a new phase in the development of tourism, speciffically rural tourism which should be one of the main carriers of tourism and a factor of integral development of rural areas (Todorović and Bjeljac 2009).

Vojvodina Province, at the north of Serbia, as an agricultural and multiethnic area has numerous potential for sustainable rural and cultural tourism development. Melting point of different cultures, religions and nationalities, rural festivities and picturesque villages are the base of anthropogenic rural tourism attractions in Vojvodina Province (Dragićević et al. 2011).

More than 24 ethnic groups with their authentic traditions, culture and language make up a rich ethnic diversity. As a result of multi-ethnicity, there is a large number of museums and other cultural institutions. They are an important element of attractiveness and should be given special attention in the policy of tourism development. In the area of Sombor and Apatin there are a number of cultural institutions, and the private museums, which are part of the tourist offer of this area, are also of great importance. The paper will cover the Museum of silk damask in Bezdan, Tobacco Museum in Telečka and the Ethnological Exhibition in Kupusina. These are museums that are located in rural, underdeveloped areas. As Europe's rural areas attract visitors to different regional, social and cultural heritage (Hall 2004), it is clear that these museums are potential tourist destinations, for both domestic and foreign tourists who want to experience rural atmosphere and meet the cultural heritage and tradition of this area.

\section{Literature review}

Museums have traditionally been spaces where a society can celebrate its past and form a sense of its cultural identity (Urry 1996). Over the last decades, however, there has been increasing attention to a »cultural revival« of heritage experiences as popular leisure and urban tourism activities. Politicians and planners

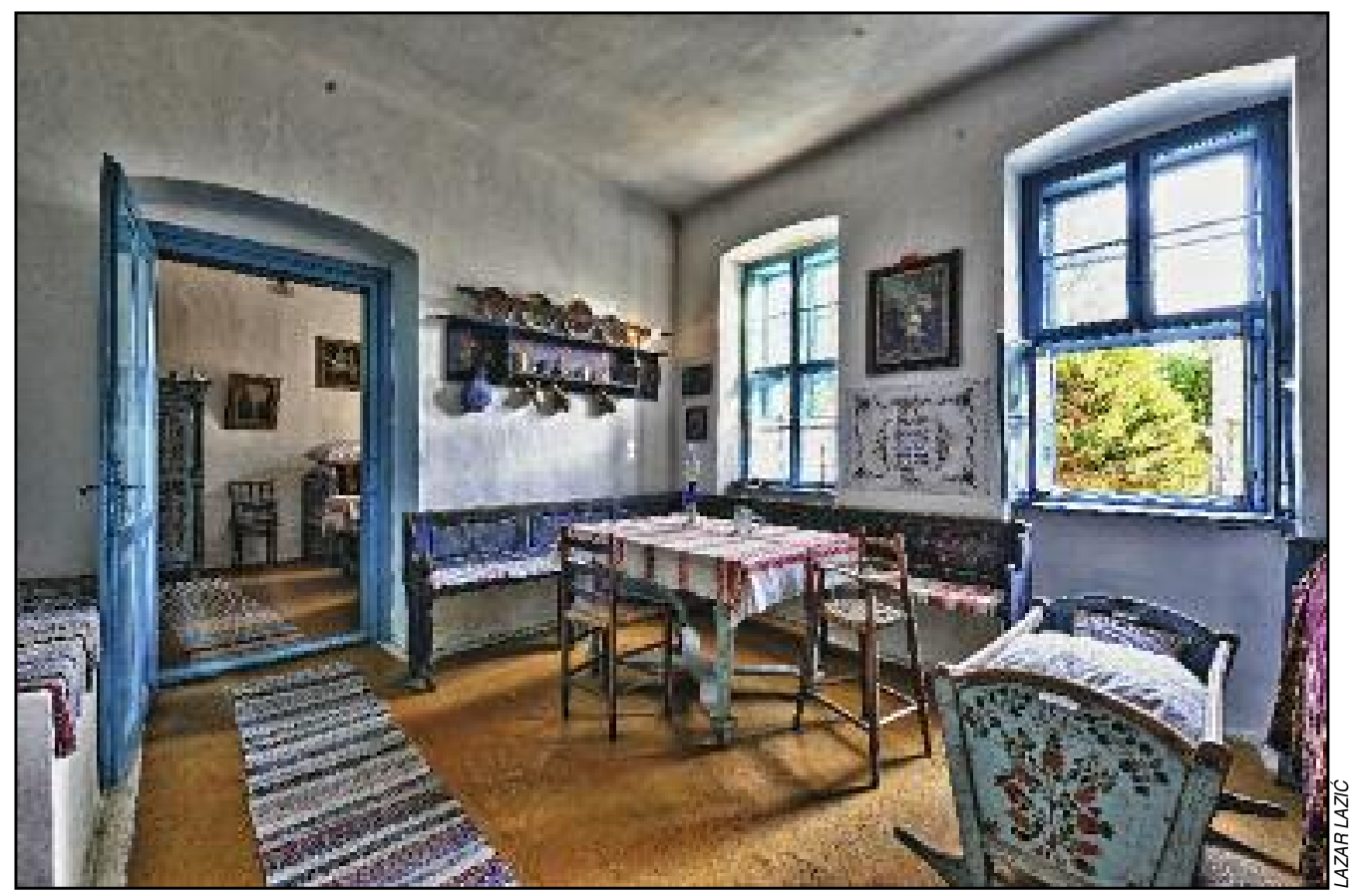

Figure 1: Ethnological Exhibition in Kupusina. 


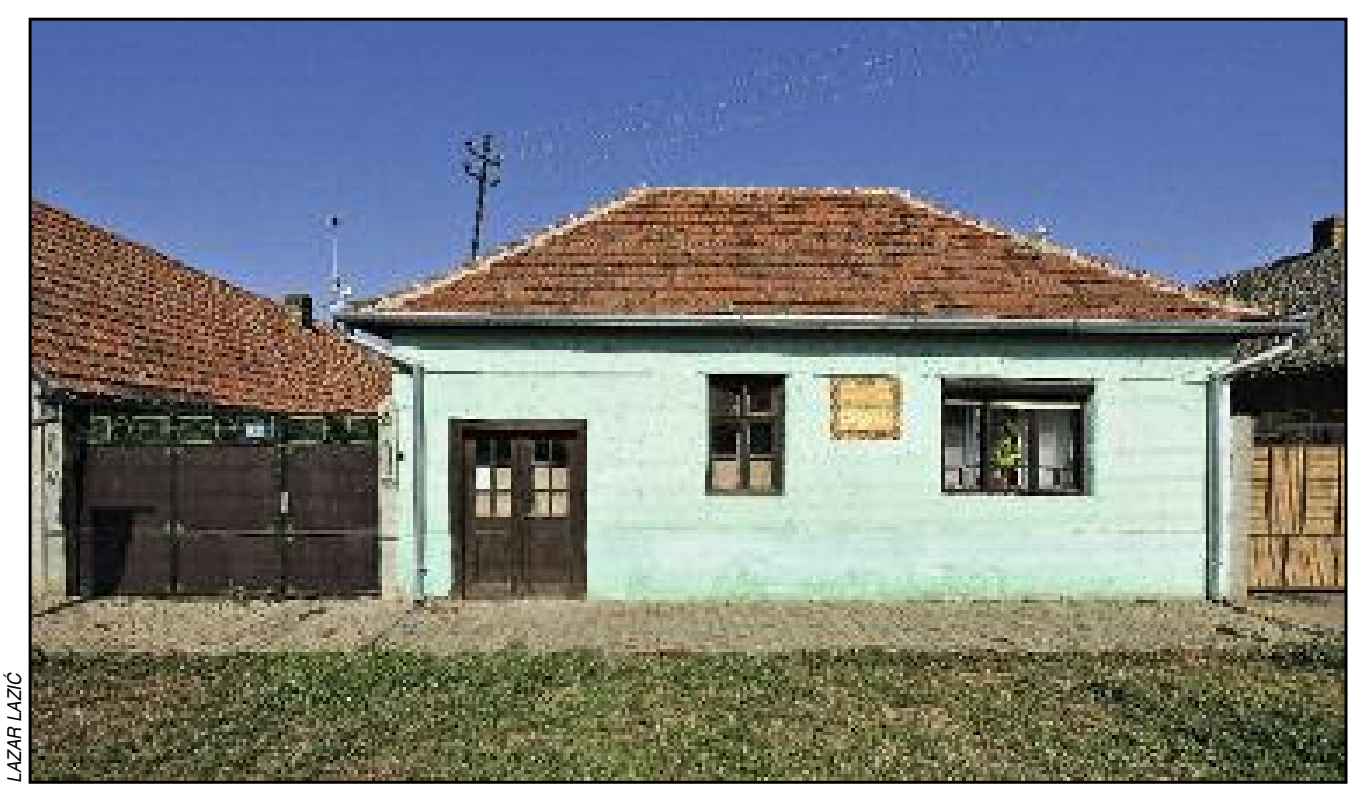

Figure 2: Tobacco Museum in Telečka.

have taken the opportunity to integrate museums into economic development initiatives in both large and small urban centres (Vaughan and Booth 1989; Zukin 1995). The growing importance of museums as cultural attractions has drawn the attention of tourism researchers for some time, but most of the work to date emphasizes demand side issues (Harrison 1997). Their unique architectural styles and exhibits give tourists "something distinctive to gaze upon" (Tufts and Milne 1999). In modern times, museums serve the functions of collection, research and exhibition, as well as education and recreation (Sheng and Chen 2012).

During the 80 's and 90 's, primarily due to the implementation of effective cultural management and access to private funds, there was a growing number of founded private museums in Europe (Balkankult fondacija 2009). Around 1718 private museums in the UK annually attract 80 million tourists. Similar numbers were recorded in Germany and other developed Western nations. In Serbia there are 104 registered private collections, with an indication that there's more. Their idea and survival are based on individual effort and passion, without real support within the system, and are often unknown and insufficiently accessible to the public (Internet).

Tourist valorisation of cultural goods, i.e. estimation of their value from the standpoint of tourism is of utmost importance in the management of cultural resources and planning for sustainable development of cultural tourism in a given destination.

Hilary du Cros (2000) introduces the process of touristic evaluation of destination, cultural-touristic sub-indicators and the degree of their graduation. The model is very complex and complete, since it evaluates the tourist, as well as the cultural resources management sector, along with the assessment of the robustness of the cultural property to accommodate visitors (Hadžić 2005). To assess the tourist importance of the Ethno Exhibition in Kupusina, the Weaving Museum in Bezdan and the Tobacco Museum in Telečka, an assessment of sub-indicators will be carried out for the tourist sector and the management of these cultural assets.

\section{Methodology}

This chapter describes the model by Hilary du Cros (2000), which was applied in this study to assess the touristic importance and management of the three museums in the territory of Apatin and Sombor. The model includes the assessment of the tourist sector and the management of cultural heritage. 
Touristic sector is represented by two sub-indicators: market attractiveness of cultural assets ( 9 indicators) and the factors important for designing of tourism product (4 indicators) (Table 2). Sub-indicators are graded by marks 0 to 5, but certain indicators have different ranks of marks. The grades are later summed up and market attractiveness of cultural assets is evaluated. After that the sum is ranked as: low attractiveness (0-20), medium attractiveness (21-40), high attractiveness (41-60) for tourism development.

The sector of cultural asset management also contains two sub-indicators: cultural importance ( 7 indicators) and robustness ( 7 indicators). Sub indicators of this sector are graded by different grades, and the conclusion on sub-indicators of cultural importance/robustness for the sector of cultural asset management is evaluated as sensitivity/low cultural value, medium value, and high value. Based on the conducted analysis, "market attractiveness/robustness matrix " consisting of 9 cells is set up and marked with $\mathrm{M}(\mathrm{i}, \mathrm{j})$, $(i, j=1,2,3)$. For every cultural asset it is determined to which cell it belongs, depending on the grade that it previously was assigned in the process of evaluation (Hadžić 2005; Besermenji and Pivac 2008). The cells are defined as in Table 1.

Table 1: Matrix of market attractiveness and robustness.

\begin{tabular}{|c|c|c|c|c|}
\hline Robustness & 41-60 high & $M(1,1)$ & $M(1,2)$ & $\mathrm{M}(1,3)$ \\
\hline & 21-40 medium & $M(2,1)$ & $M(2,2)$ & $\mathrm{M}(2,3)$ \\
\hline & 0-20 low & $\mathrm{M}(3,1)$ & $\mathrm{M}(3,2)$ & $\mathrm{M}(3,3)$ \\
\hline & & 0-20 low & 21-40 medium & 41-60 high \\
\hline & \multicolumn{4}{|c|}{ Market attractiveness } \\
\hline
\end{tabular}

Evaluation of sub-indicators from the tourist sector and the sector of cultural heritage management was done by 3 people, 2 art historians and 1 tourist agent.

\section{Results}

Survey results will be analyzed by introducing the average score for sub-indicators from the tourism sector (Table 2) and the management of cultural heritage sector (Table 3 ).

\section{Tourism sector}

For all three analyzed cultural properties, the environment can be estimated as adequate (score of 3 on a scale of $0-1$ weak, 2-3 adequate, good 4, great 5), because museums are located in the rural areas themselves, which have the characteristics of typical villages of Vojvodina.

Museums are not known outside the local area and do not represent an important national symbol, so the score is 0 , but an interesting story can be told about them (score 3 on a scale of 0 meaning not, $1-3$ has potential, $4-5$, yes).

The Weaving Museum has some potential, because of an interesting story about Janos Schmidt, who was an artistic weaver. Also, at the Museum of Tobacco, the stories related to the making of cigars are interesting. The Ethno Exhibition in Kupusina has an interesting story about the customs and daily life of rural Hungarian families.

The indicator » The site is different from other nearby cultural assets « is evaluated on the scale not $0-1$, adequate $2-3$, good 4 , very good 5 . Of the three analyzed cultural properties only the Weaving Museum, has certain potential, which clearly differentiates it from other cultural goods and therefore can be evaluated with a score of excellent (5), because there are looms from the $19^{\text {th }}$ century in museums in France and Egypt, however, they are exposed as exhibits and are no longer in operation.

All three cultural assets are not suitable for occasional adaptation for special purposes (grade 0), but have a potential to be complementary to other tourism products at the destination, and within the region, therefore the grade is 3 (not at all 0, has a potential 1-3, very good 4-5). The Kupusina Ethno Exhibition is located near the Gornje Podunavlje nature reserve and the towns of Sombor and Apatin. In addition to the Weaving Museum, in Bezdan there is an Iodine Spa and lock from the Danube to Danube-Tisa-Danube Canal, which is a cultural monument of great importance. In Telečka, in addition to the Tobacco Museum, there is a museum of antiques and clocks, and the settlement itself is near Sombor and Bačka Topola. Still, the tourist activity in the region is low (score 0 ). 
For the indicator »Associated with culture « on a scale of $0-$ not at all, $1-3-$ and has a potential $4-5$ completely, the ethno Exhibition in Kupusina received the highest score (4) because it represents the culture of the Hungarian people. The Weaving Museum received a score of (2), that is, it has potential, because multi-ethnicity is represented in the culture of the Bezdan population, since more than half of the population are Hungarians and Serbs make up a quarter.

Table 2: The evaluation of the cultural assets by $\mathrm{H}$. du Cros model - indicators of tourism sector.

\begin{tabular}{lccc}
\hline Indicators & $\begin{array}{c}\text { Ethno Exhibition } \\
\text { in Kupusina }\end{array}$ & $\begin{array}{c}\text { Weaving } \\
\text { Museum }\end{array}$ & $\begin{array}{c}\text { Tobacco } \\
\text { Museum }\end{array}$ \\
\hline
\end{tabular}

\section{Market attractiveness}

Ambience

The site renowned beside local area

The important national symbol

Evocative place

The site different from other nearby cultural assets

The site's attractiveness for special purposes

Complementary to other tourism products at the destination

Tourist activity within the region

Associated with culture

3
0
0
3
0
0
3
0
4

\section{Factors important for design of tourism product}

The accessibility of cultural asset

Transportation from population center to cultural asset

The proximity of other cultural assets

Service availability

Total

\begin{tabular}{rrr}
4 & & \\
1 & 4 & 4 \\
1 & 3 & 3 \\
2 & 3 & 3 \\
$\mathbf{2 1}$ & 2 & 2 \\
\hline
\end{tabular}

Further analysis is based on the evaluation of factors important for design of tourism product.

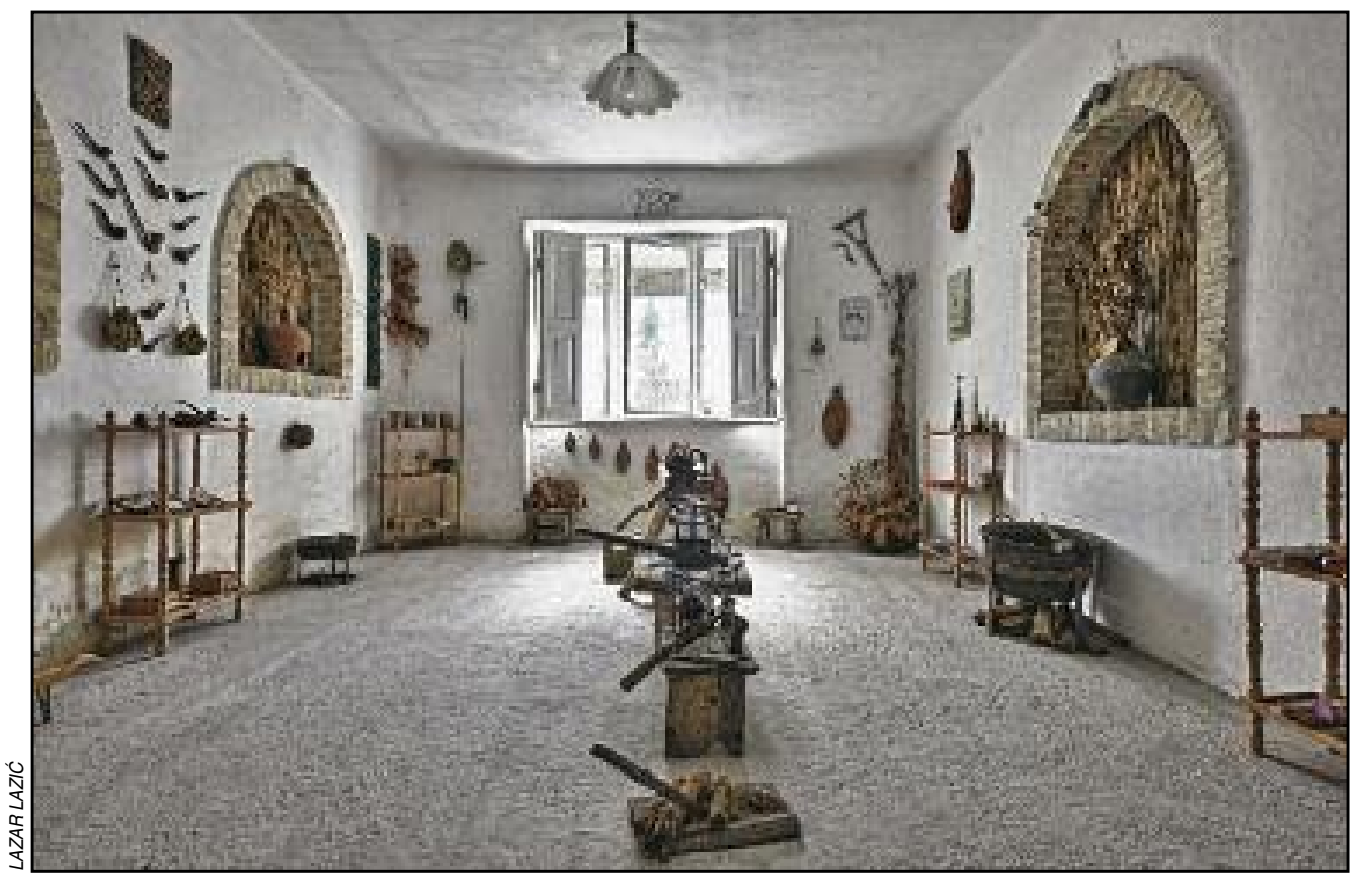

Figure 3: Interior of Tobacco Museum in Telečka. 
The accessibility to the cultural assets is good, due to its location in villages and close to larger towns. The access to all of the cultural assets is allowed, and all of the assets are open for visitors. Therefore, the grade for accessibility is 4 (not allowed 0, limited 1-2, allowed access to all assets 3-4).

For the indicator of proximity of other cultural assets, the Ethno Exhibition in Kupusina received a lower grade 1 (long distance / difficult access 0, 1-2 enabled access, easy access 3), while the Weaving Museum and Tobacco Museum received the highest ratings (3). The Weaving Museum is located near the lock on Danube, built in 1856. It is an important industrial and architectural monument, because it is the first concrete structure of its kind in Europe, where underwater concreting was implemented. The Tobacco Museum is located in the vicinity of the Museum of Antiquities and Clocks. Service benefits (parking, marked roads to cultural landmarks, refreshments, access to information) are adequate. For all three cultural assets the grade is 2 (weak 0 , adequate $1-2$, good $3-4$, and great 5 ).

Total score of indicators of the tourism sector for the Kupusina Ethno exhibition is 21, for the Weaving Museum it is 28 , and for the Tobacco Museum it is 23 , that is, the degree of market attractiveness is medium (weak attractiveness 0-20, medium attractiveness 21-40, high attractiveness 41-60).

Sector of cultural asset management

The aesthetic value is high for the Ethno Exhibition in Kupusina and the Weaving Museum, while at the Museum of Tobacco the aesthetic value is medium (0 low, medium 1, high 2). In the Ethno exhibition in Kupusina there are original Hungarian folk costumes, which have a great aesthetic value because of specific motives for decorating. In addition, the exhibition also includes original rural furniture in »Kupusina" blue. Products of the Weaving Museum have a high aesthetic value. Production is done on hand looms jacquard fabric with punch cards, which also date from 1871.

Table 3: The evaluation of the cultural assets by $\mathrm{H}$. du Cros model - indicators of cultural assets management sector.

\begin{tabular}{|c|c|c|c|}
\hline Indicators of cultural asset management & $\begin{array}{l}\text { Ethno Exhibition } \\
\text { in Kupusina }\end{array}$ & $\begin{array}{l}\text { Weaving } \\
\text { Museum }\end{array}$ & $\begin{array}{l}\text { Tobacco } \\
\text { Museum }\end{array}$ \\
\hline \multicolumn{4}{|l|}{ Cultural importance } \\
\hline Aesthetic value & 2 & 2 & 1 \\
\hline Historical importance & 1 & 2 & 2 \\
\hline Educational value & 2 & 2 & 2 \\
\hline Social value & 0 & 0 & 0 \\
\hline Scientific value & 2 & 0 & 0 \\
\hline Rareness of the cultural asset at the destination & 1 & 3 & 2 \\
\hline Representativeness of the site & 2 & 1 & 1 \\
\hline \multicolumn{4}{|l|}{ Robustness } \\
\hline The sensitivity of the cultural asset & 0 & 0 & 3 \\
\hline Reparation status & 0 & 1 & 1 \\
\hline Existence of the management plan of the cultural asset & 2 & 3 & 0 \\
\hline Regular monitoring and maintenance & 2 & 4 & 1 \\
\hline Potentials for investments and consultations of the key stakeholders & 3 & 3 & 0 \\
\hline Possibility of tourists negatively affecting the physical state of the site & 2 & 1 & 2 \\
\hline $\begin{array}{l}\text { Possibilities of modification, as a part of product development, that } \\
\text { would have the negative influence on physical state of cultural asset }\end{array}$ & 3 & 5 & 3 \\
\hline Total & 22 & 27 & 18 \\
\hline
\end{tabular}

The historical value of the Ethno Exhibition in Kupusina is medium (1), as it testifies to the life of rural people of Hungarian origin, in the past in this region, while the historical value of the Weaving Museum is high (score 2), as it presents the technology in textile production in the second half of the $19^{\text {th }}$ century. Also, the Museum of Tobacco has a high historical value, because it presents the tobacco production technology in the second half of the $19^{\text {th }}$ century.

Educational value is high (low 0, medium 1, high 2) for all three cultural assets. By getting to know the objects in the Ethno Exhibition in Kupusina, one can learn, what life used to be in a rural Hungarian household in this region during the $18^{\text {th }}$ and $19^{\text {th }}$ century, what was the main economic activity, what food was prepared and how people dressed. In the Weaving Museum visitors can learn about the method of production and the raw composition of the finest silk batiste, while the tobacco museum visitors can get acquainted with the way of cultivation of tobacco, its processing, production of cigarettes, cigars, perfume and the tanning liquids. 


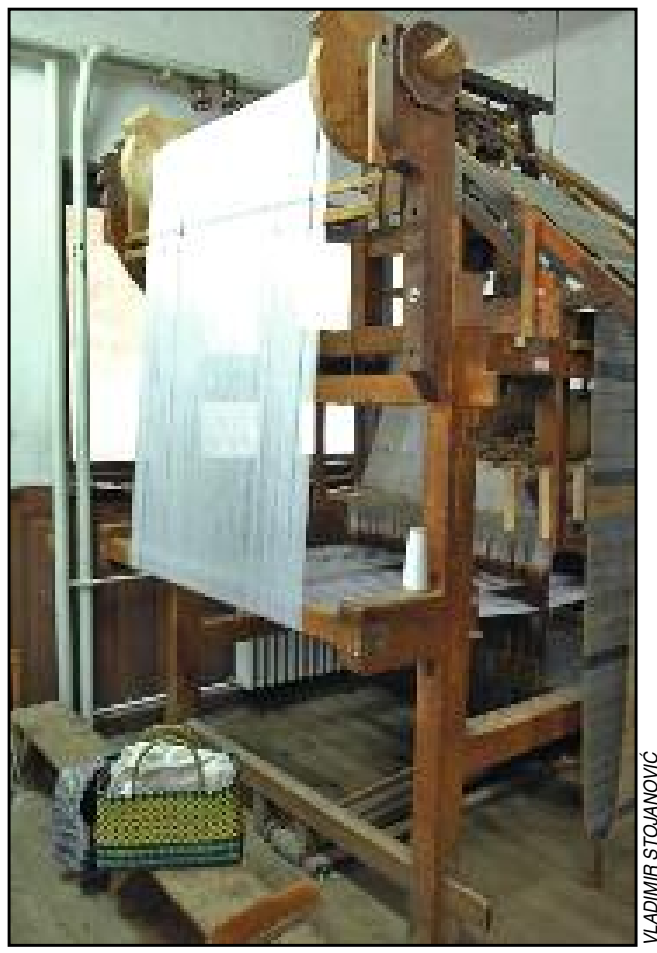

Figure 4: Weaving Museum in Bezdan.

Although the historical, aesthetic and educational value of these cultural properties are recognized, their social value is low (score 0 on a scale of 0 to 2 ).

Scientific and research value the Ethno Exhibition in Kupusina is high (2), because it can be used for ethnographic research, while for the remaining two cultural goods, this value is low. The Ethno Exhibition in Kupusina is an unusual cultural asset (grade 1), while the Weaving Museum is a unique cultural heritage (the highest grade 3), because, although there are hand looms on permanent display in museums of France and Egypt, they are no longer in operation. Also, the Tobacco Museum can be evaluated as a rare cultural asset (score 2), because it is the only tobacco museum in the region. Representativeness of the Ethno Exhibition in Kupusina is good (grade 2), while representativeness of the Weaving Museum and the Museum of Tobacco are considered to be weak (grade 1) (weak 1, good 2-3, great 4).

On the scale from 0 to 4 (very sensitive 0-1,2-3 sensitive, insensitive 4), Ethnic Exhibition in Kupusina and Weaving Museum are considered to be very sensitive cultural assets (grade 0), as the permanent exhibition in Kupusina is furniture and the rural household furnishings and clothing, which are extremely sensitive to low temperature, high temperature and humidity. The Weaving Museum has 18 looms and two Spül weaving machines which have been in use since 1871 so they are apt to decay. Also, at the Tobacco Museum, the tobacco and tobacco products are sensitive to humidity and temperature changes, due to the age of the exhibits.

The state of repair in Kupusina is weak (0), because the objects in the exhibition cannot be renewed, due to old age, and this is especially true for items of clothing, while the other two cultural goods have been partly repaired - rating 1 (weak 0 , partly repaired $1,2-3$ good, great 4 ).

The cultural heritage management plan is being prepared or the plan does not exist, therefore the estimates are different (not existing 0 , in preparation 1-4, exists 5).

Regular monitoring and maintenance of the cultural assets (weak 0, in certain amount 1-2, good 3-4, great 5) are present in certain amount at Ethno Exhibition in Kupusina (grade 2) and Tobacco Museum (grade 1), while in Weaving Museum it is good (4), because the machines work every day in the production of damask, so monitoring is common, and maintenance is in accordance with the needs of intensive production. 
Potentials for investments and consultations of the key stakeholders are good (3) at Ethno Exhibition in Kupusina, because it is possible to extend the activity, in terms of equipping the space for souvenirs and service industries, and in Weaving Museum, because it is possible to equip a separate area in the existing facility for display of damask products. In Tobacco Museum, potentials for investments are weak.

Possibility of a negative impact of a large number of visitors to the physical state of the Ethno Exhibition in Kupusina and Tobacco Museum is medium ( 2 on a scale 1 - great possibility, 2-4 medium, 5 small possibility). In the case of a large number of visitors it would be difficult to track their movements due to lack of space in both objects.

The possibility that modification as part of product development, has a negative impact on the physical condition of the Ethno Exhibition in Kupusina and the Tobacco Museum is medium (3) on a scale of 1-great possibility, 2-4 medium, and small possibility 5 because landscaping for service activity might have a somewhat negative impact on the physical condition of the traditional country house, in which the exhibition is set. In the case of Weaving Museum, the rating is 5, because it would be possible to conduct modifications in a room that does not contain looms and machines.

The total rating of indicators for the sector of cultural heritage management exhibition for the Ethno Exhibition in Kupusina and Weaving Museum is 27 which is medium quality, while for the Museum of Tobacco the rating is somewhat lower at 18 , which means little cultural value (sensitivity / low cultural value of 0 to 20, medium value 21-40 and high value 41-60).

Based on the analysis and the matrix of "market attractiveness/robustness « (Table 3), it is concluded that the Ethno Exhibition in Kupusina and Weaving Museum pertains to the category M (2.2), medium value of indicators of cultural importance/robustness and medium market attractiveness, while Tobacco Museum is in category M (3.2) - low value of indicators of cultural importance/robustness and medium market attractiveness (Table 4).

Table 4: Matrix of market attractiveness and robustness for the analyzed cultural goods.

\begin{tabular}{lcccc}
\hline \multicolumn{5}{c}{ Ethno Exhibition in Kupusina } \\
\hline Robustness & $41-60$ & $M(1,1)$ & $M(1,2)$ & $M(1,3)$ \\
& $\mathbf{2 1 - 4 0}$ & $M(2,1)$ & $\mathbf{M}(\mathbf{2}, \mathbf{2})$ & $\mathrm{M}(2,3)$ \\
$0-20$ & $\mathrm{M}(3,1)$ & $\mathrm{M}(3,2)$ & $\mathrm{M}(3,3)$ \\
& $0-20$ & $\mathbf{2 1 - 4 0}$ & $41-60$
\end{tabular}

\begin{tabular}{|c|c|c|c|c|}
\hline \multicolumn{5}{|c|}{ Weaving Museum } \\
\hline Robustness & $\begin{array}{c}41-60 \\
\mathbf{2 1 - 4 0} \\
0-20\end{array}$ & $\begin{array}{c}\mathrm{M}(1,1) \\
\mathrm{M}(2,1) \\
\mathrm{M}(3,1) \\
0-20\end{array}$ & $\begin{array}{c}M(1,2) \\
\mathbf{M}(\mathbf{2}, \mathbf{2}) \\
M(3,2) \\
\mathbf{2 1 - 4 0}\end{array}$ & $\begin{array}{l}M(1,3) \\
M(2,3) \\
M(3,3) \\
41-60\end{array}$ \\
\hline
\end{tabular}

\begin{tabular}{|c|c|c|c|c|}
\hline \multicolumn{5}{|c|}{ Tobacco Museum } \\
\hline Robustness & $\begin{array}{l}41-60 \\
21-40 \\
\mathbf{0 - 2 0}\end{array}$ & $\begin{array}{c}M(1,1) \\
M(2,1) \\
M(3,1) \\
0-20\end{array}$ & $\begin{array}{c}M(1,2) \\
M(2,2) \\
\mathbf{M}(\mathbf{3}, 2) \\
\mathbf{2 1 - 4 0}\end{array}$ & $\begin{array}{c}\mathrm{M}(1,3) \\
\mathrm{M}(2,3) \\
\mathrm{M}(3,3) \\
41-60\end{array}$ \\
\hline
\end{tabular}

The formation of the tourism product should include a visit to the cultural good that, after evaluating, occupies cells $\mathrm{M}(2,3)$ and $\mathrm{M}(1,3)$. A visit to a property with middle and high market appeal, but small values of indicators of cultural significance / robustness, cells $\mathrm{M}(3,2)$ and $\mathrm{M}(3,3)$ may be provided but only after providing such cultural asset management, which will prevent its damage during the visit of tourists. Those cultural goods with low market attractiveness cannot be the key attractions that will attract large numbers of tourists $\mathrm{M}(3,1)$. Cultural goods with high or average value of indicators of cultural significance / robustness and mediocre market appeal, cells $M(1,2)$ and $M(2,2)$ should be promoted in a qualitative way, but also drawn to the attention of conservationists and managers of cultural heritage in order to determine an optimum number of visitors for sustainable tourism. 


\section{Conclusion}

The evaluation of the tourist attractiveness and cultural assets management sector by H. du Cros model showed that it is necessary to pay attention to the conservation of museums, carrying capacity and visitors management. The process of restoration and conservation needs to be more regular and should be the result of experts' assessment, who will determine the required level of robustness and the period of revitalization. Also, the results of the study show that it is necessary to promote cultural assets in a better way, including adequate and differentiated use of promotional instruments. All these actions would lead to tourism development in this area and consequently should have positive economic and social impact on local ppulation. Economic factors as well as socialization are percieved by local residents in Sombor and Apatin as very important in cultural tourism development (Blešić et al. 2014).

Future studies on the tourism attractiveness and management of cultural assets in Vojvodina Province should be based on the tourists' perception. Also, stakeholders involved in tourism development could be asked to evaluate the attractiveness of the region or specific cultural values. The best results would be achieved through comparison of tourists' and stakeholders' opinions on Vojvodina tourist attractiveness.

\section{Acknowledgment}

This study resulted as a part of National projects National project Ministry of Education and Science, Republic of Serbia No. 47024.

\section{References}

Balkankult fondacija, 2009. Projekat: Razvoj privatnih kolekcija/muzeja u Vojvodini Pilot istraživanje. Internet: www.balkankult.org/bk/files/506/en/Pilot_istrazivanje.pdf (31.8.2012).

Blešić, I., Pivac, T., Đorđević, J., Stamenković, I., Janićević, S. 2014: Cultural events as part of cultural tourism development. Case study: Sombor and Apatin (Serbia). Acta Geographica Slovenica 54-2. Ljubljana. DOI: $10.3986 /$ AGS54406

Besermenji, S., Pivac, T. 2008: Turistički značaj Sirmijuma. Collection of the Papers. Geographical Faculty, University of Belgrade LVI. Belgrade.

Dragićević, V., Stankov, U., Arsenović, D. 2011: The Attractiveness of Vojvodina Province as a Tourist Destination on the Basis of Domestic Tourists' Perception. Geographica Timisiensis 20-1. Timisoara.

Du Cros, H. 2000: Planning for Sustainable Cultural Heritage Tourism in Hong Kong. Final Report to the Lord Wilson Heritage Trust Council. SAR.

Hadžić, O. 2005: Kulturni turizam. Departman za geografiju, turizam i hotelijerstvo. PMF. Novi Sad.

Hall, D. 2004: Rural Tourism Development in Southeastern Europe: Transition and the Search for Sustainability. International Journal Of Tourism Research 6-3. DOI: 10.1002/jtr.482

Harrison, J. 1997: Museums and Touristic Expectations. Annals of Tourism Research 24.

Internet: http://www.politika.rs/rubrike/Kultura/t49776.lt.html (19. 10. 2012).

Sheng, C., Chen, M. 2012: A study of experience expectations of museum visitors. Tourism Management 33-1. DOI:10.1016/j.tourman.2011.01.023

Todorović, M., Bjeljac, Z. 2009: Rural tourism in Serbia as a way of development in undeveloped regions. Acta geographica Slovenica 49-2. Ljubljana.

Tufts, S., Milne, S. 1999: Museums a Supply-Side Perspective. Annals of Tourism Research 26-3. DOI: http://dx.doi.org/10.1016/S0160-7383(99)00024-9

Urry, J. 1996: How Societies Remember the Past. Theorizing Museums, Representing Identity and Diversity in a Changing World. 145-167. Oxford.

Vaughan, D. R., Booth, P. 1989: The Economic Importance of Tourism and the Arts in Merseyside. Journal of Cultural Economics 13-2. DOI 10.1007/BF00208542

Zukin, S. 1995: The Cultures of Cities. New York. 